\title{
Tri Hita Karana and Tourism Village Management Models for Wellbeing
}

\author{
Ni Ketut Sari Adnyani \\ niktsariadnyani@gmail.com \\ Universitas Pendidikan Ganesha \\ I Gusti Ayu Purnamawati \\ igapurnamawati@gmail.com \\ Universitas Pendidikan Ganesha
}

\begin{abstract}
This study aims to analyze the traditional law community unit is examined by emphasizing the concept of Tri Hita Karana as a reference for village spatial planning, village buildings, and harmonization with cultural and environmental conservation in Penglipuran village. Based on field surveys, several attractions in Indonesia have not heeded the concepts of Tri Hita Karana, Tri Mandala, and Asta Kosala-Kosali. Sample of this study were the traditional village officers and associations of the Indonesian Hotels and Restaurants Association to test the model of the tourism village that imply the humanist integration of indigenous peoples empowerment. Statistical analysis is based on survey data and records of the amount of environmental damage due to high tourist activity. The results of this study shows that mutual humanist synergy is a collective nature of indigenous peoples and tourism service actors leading to environmentally friendly cultural ecotourism. The steady culture of the survival of traditions, customs, and ancestral culture has an impact on sustainable tourism development. The environmentally unconscious behavior becomes a challenge. Prevention of environmental damage can be overcome by offering a model of the Penglipuran tourism village as a universal model with environmental balance characteristics.
\end{abstract}

\section{Keyword : tourism village management models}

\section{Introduction}

Although the concept of customary international law is difficult to understand, some clear norms emerge internationally through the customary law-making process. Why does it have to state that it adheres to customary norms? (Baker, 2010). In contrast to the explanatory question as to why the norm arises, this question is normative rather than empirical it demands an investigation on the basis of legal obligation(Priambodo, 2018). One possibility is to focus on causal questions: what are the economic, social, psychological, and political processesexplain the emergence of customary norms? To what extent, for example, do customary norms emerge as a result of rational self-interest calculation by the state?The International Law Association (ILA) and the International Law Commission (ILC) have done the task of clarifying the rules regarding the formation and identification of customary international law (CIL). In 2000, the ILA adopted the London Principles Statement that Applied to the Establishment of (General) Customary International Law (with comments) consisting of thirty-three principles(International Law Association, London Conference \& Law, 2000). What can be identified in the literature is what distinguishes between "traditional" and "modern" CIL, with the latter relying on inclusive ideas about state practices (thus for example incorporating international organizational resolutions) and a relatively greater emphasis on the elements of opinojuris(Baker, 2010).

The concern that CIL receives is that "a large part of the national law system now recognizes habits as being directly applicable, at least in principle. In Indonesia there are 19 regional customary laws, such as Gempong in Aceh, Villages in Java, Nagari(Azwar et al., 2019). The participation of indigenous peoples in developing tourism potential as a strategic effort to develop community-based tourism (CBT) is often seen as one component of a broad-based plan to improve the rural economy. CBT development is characterized as a form of development located in an area that uses tourism to produce economic, social and cultural benefits in a 
community (Johnson, 2010). Population migration through desertification has influenced the socio-economic and cultural development of the Jordanian desert(Saleh, 2016), in Indonesia also experienced the same thing. In this article, we focus on the idea of empowering indigenous peoples by coordinating with the Hotel and Restaurant Association. An innovative model of tourism village development as a form of mutual relations between tourism actors and traditional villages motivates cultural tourism activities that are thick with the ties of tradition, customs, and religion to influence the culture of tourism villages. This model emerged as a response to the condition of the tourist area which tends to ignore the right of unity of indigenous and tribal peoples where criticisms that refer to the context of external private investment development seek to enter rural communities. For example, a private developer can buy land in a community to build or open a tourism business, such as a hotel or resort, and then seek out public input on the scale, design, and nature of structures. In this way, the community is the target of development outcomes, rather than being an equal partner in the process of developing rural tourism(Riddle \& Thompson-Fawcett, 2019).

Penglipuran as a model village because since 2016 representing the Bali provincehas become one of the pioneers of successful tourism villages in Indonesia, and abroad. Specifically, the effectiveness of the cultural tourism model with Penglipuran as a pilot so that it can be used as a reference by other regions throughout Indonesia. We investigate the plausibility of the universal model for the fulfillment of the rights of indigenous peoples in the management of cultural tourism villages by examining findings from empirical studies. After presenting the background, arrangement and fulfillment of the rights of indigenous peoples in Indonesia, we present a literature review of the cultural tourism village and the Penglipuran village as a cultural tourism pilot village and illustrate the findings of previous research on the empowerment of indigenous peoples in cultural tourism villages. We then compare these findings with similar survey data we collected throughout Indonesia in 2018-2019 and conclude with a discussion of implementation.

\section{Literature Review}

The concept of Tri Hita Karana basically contains an understanding of human adaptation patterns to their environment (spiritual environment, social environment, and physical environment) in various dimensions of space and time. It contains universal values for the welfare of human life and the universe(Purnamawati et al., 2015). The concept of Tri Hita Karana-based Tourism is gaining international attention and is often an important agenda at international tourism meetings, such as the Asean Standard Hotel Workshop in Bangkok (2004), the World Tourism Organization Meeting in Cambodia (2004), and the Pata Conference in Jeju, South Korea (2014). The implementation of Tri Hita Karana in tourism development basically controls the libido of the tourism industry's capitalism by instilling moral awareness and religious ethics (parhyangan), humanity (pawongan), and the environment (palemahan). Thus the implementation of tourism activities is not profit oriented, but also able to increase the dignity of human beings as cultured creatures and environmental conservation in a sustainable manner.

The manifestation of parhyangan aspects in the tourism industry which has implications for the revitalization of local religious values, is not only important for the inner well-being of humans, but also provides a distinctive style and nuance to tourism itself. Manifestation of pawongan aspects in tourism management positions the social institutions of the local community as a reference for patterns of good relations between tourism actors and between tourism actors and the local social environment. This not only has implications for the creation of harmonious relationships between people as social beings, but also revitalizes the social fabric of the local community. Likewise, the embodiment of the weak aspects of tourism management upholds ecological wisdom derived from traditional culture. In connection with the growing discourse on the global ecological crisis, the existence of traditional cultural aspects such as traditional knowledge and belief systems is seen as forms of ecological wisdom that function quite effectively as a control mechanism for environmental management (Ojha et al., 2019). 
Penglipuran Tourism Village Management is a tourism management model based on Tri Hita Karana, a tourism management model that is based on a philosophical harmonious relationship between humans and the spiritual environment (parhyangan), social environment (pawongan), and physical environment (palemahan). In the context of tourism, parhyangan aspects relating to the religious system and pawongan aspects relating to the ecological system function as potential attractions or attractions. While the aspect of pawongan related to the social environment system, besides functioning as an attraction or tourist attraction, it also acts as a tourism actor or manager. Tourism management is based on the principles of harmonious relations between actors or managers of tourism and the spiritual environment, social environment. and the physical environment in turn has positive implications in the form of economic benefits or contributions to aspects of pawongan, the revitalization of musty parhyangan, and conservation of the disadvantage aspect.

\section{Results and Discussion}

\subsection{Excellent Potential Assessment of Penglipuran Cultural Tourism Village}

Penglipuran cultural tourism village has the potential of cultural and natural resources which can be used as a potential for village tourism planning(Sugiama, 2019). The potential resource is supplied by the assessor using questionnaire media. The assessor assessment was carried out by 3 assessors consisting of the PenglipuranVillage secretary, the treasurer of the Penglipuran Village and the head of the Penglipuran traditional village environment. The results of the assessor's assessment produced ten resources that could be used as potentials for village ecotourism planning including the tradition of matching braya (MB); traditional building (BT); traditional dress code (TCBT), traditional tilapia food (MTMN), environmental cleanliness (KL), angklung musical instrument (AMA), uniformity of house angkul (KAAR), mepeed festival (FM), agricultural landscape (AMA) BAP) and the external resources are TNGC (TNGC). An assessment of the superior potential of Penglipuran village can be seen in Table 1.

Table 1. Excellent Potential Assessment of Penglipuran Village

\begin{tabular}{llrrrrrrrrrr}
\hline No & Indicator & MB & BT & TCBT & MTMN & KL & AMA & KAAR & FM & BAP & TNGC \\
\hline 1 & Uniqueness & 7 & 5 & 6 & 6 & 7 & 7 & 7 & 6 & 6 & 7 \\
2 & Scaecity & 6 & 4 & 6 & 5 & 7 & 7 & 7 & 5 & 6 & 7 \\
3 & Beauty & 4 & 4 & 5 & 6 & 6 & 7 & 7 & 7 & 7 & 7 \\
4 & Seasonality & 6 & 4 & 4 & 5 & 6 & 6 & 7 & 4 & 4 & 5 \\
5 & Sensitivity & 4 & 5 & 4 & 5 & 5 & 5 & 6 & 4 & 4 & 5 \\
6 & Accessibility & 7 & 5 & 5 & 5 & 6 & 5 & 7 & 6 & 6 & 6 \\
7 & Function & 7 & 7 & 4 & 6 & 6 & 6 & 7 & 4 & 5 & 7 \\
8 & Social & 7 & 6 & 4 & 4 & 5 & 7 & 7 & 4 & 5 & 7 \\
\hline & Average & 6 & 5 & 4,75 & 5,25 & 6 & 6,25 & 6.9 & 5 & 5,4 & 6,4 \\
\hline
\end{tabular}

Source: Data Processed.

Note:

Beauty: 1. Not very beautiful, 2. Not beautiful, 3. Somewhat not beautiful, 4. Just ordinary, 5. Somewhat beautiful, 6. Beautiful, 7. Very beautiful. Uniqueness: 1. Very not unique, 2. Not unique, 3. Somewhat not unique, 4. Unremarkable, 5. Somewhat unique, 6. Unique, 7. Very unique. Scarcity: 1. Very rare, 2. Not rare, 3. Somewhat rare, 4. Unremarkable, 5. Somewhat rare, 6. Rare, 7. Very rare. Accessibility: 1. Very unaffordable, 2. Unaffordable, 3. Somewhat unreachable, 4. Unremarkable, 5. Somewhat affordable, 6. Affordable. Sensitivity: 1. Very insensitive, 2. Not sensitive, 3. Somewhat insensitive, 4. Average, 5. Somewhat sensitive, 6. Sensitive, 7. Very sensitive. Seasonal: 1. Very not seasonal, 2. Not seasonal, 3. Somewhat seasonal, 4. Unremarkable, 5. Somewhat seasonal, 6. Seasonal, 7. Very seasonal. Social Functions: 1. Very unhelpful, 2. Not useful, 3. Somewhat unhelpful, 4. Average, 5. Somewhat useful, 6. Very useful.

\subsection{Characteristics, Perceptions and Community Readiness}




\subsubsection{Characteristics of Community Respondents}

Community characteristics include gender, education status, age, origin of arrival, last education, employment and monthly income. The number of respondents interviewed was 30 respondents by random sampling. Community characteristics can be seen in Table 2 .

\section{Table 2 Community Characteristics}

\begin{tabular}{|c|c|c|c|c|}
\hline No & Characteristics & & $\begin{array}{c}\text { Person } \\
\text { number }\end{array}$ & Presentase \\
\hline \multirow[t]{3}{*}{1} & Gender & & & \\
\hline & & Man & 17 & 57 \\
\hline & & Women & 13 & 43 \\
\hline \multirow[t]{2}{*}{2.} & Marriage Status & Marriage & 23 & 77 \\
\hline & & Single & 7 & 23 \\
\hline \multirow[t]{3}{*}{3} & Age & $20-30$ & 8 & 27 \\
\hline & & $31-40$ & 14 & 46 \\
\hline & & $41-50$ & 8 & 27 \\
\hline \multirow[t]{6}{*}{4} & Last Education & Elementary School & 9 & 30 \\
\hline & & Middle School & 9 & 30 \\
\hline & & Senior High School & 3 & 10 \\
\hline & & Diploma & 1 & 4 \\
\hline & & Bachelor & 1 & 3 \\
\hline & & No School & 7 & 23 \\
\hline \multirow[t]{5}{*}{5} & Profession & Student & 6 & 20 \\
\hline & & college student & 3 & 10 \\
\hline & & Civil Servants & 1 & 3 \\
\hline & & Private Employee & 1 & 3 \\
\hline & & Farmers / Breeders & 19 & 64 \\
\hline \multirow[t]{4}{*}{6} & Monthly Income & Less Than Rp 500.000 & 2 & 7 \\
\hline & & Rp 500.000 - Rp 1.000.000 & 16 & 53 \\
\hline & & $R p 1.000 .000-R p 3.000 .000$ & 11 & 37 \\
\hline & & Rp 3.000.000 - Rp 5.000.000 & 1 & 3 \\
\hline
\end{tabular}

Source: Data Processed

The sex of the respondents interviewed was mostly men with a percentage of $57 \%$. That is because of the connection with the livelihoods of the majority Penglipuran people as farmers and ranchers. The process of caring for agricultural land requires a large enough power so that it must use male labor. Also mentioned is the care of farm land. The majority of women interviewed as respondents were housewives. The sex affects the marital status of the Penglipuran community.

The marital status of the respondents interviewed was mostly married. The percentage of respondents who were married was $77 \%$. That is because the majority of Penglipuran Village people get married before the age of 25 . The marital status is related to the age of the respondents interviewed. Most of the respondents interviewed had an age range of 30-40 years. This is related to the marital status of the respondents interviewed.

The last education of the respondent determines the livelihood undertaken. The majority of respondents do not have a formal school diploma. This affects the work of the majority of respondents who work as farmers or ranchers. The livelihood is very influential on the income earned by respondents. Respondents' income is mostly around Rp. 500,000-Rp. 1,000,000 per month. This is because sales of agricultural products and livestock have risen at certain times.

\subsubsection{Assessment of Penglipuran Communities as Ecotourism Areas}


The views of the Penglipuran Village community regarding the ecotourism area to be carried out in Penglipuran agree. That is because the average assessment of the Penglipuran community on the village's ecotourism activities is largely normal and agreed. Other assessments are common in the pilot media that will be used as a comparative study by other regions who want to program the cleanliness and structuring of a beautiful environment and the preservation of traditional values. Public perception can be seen in Table 3.

Table 1. Community Perception

\begin{tabular}{|c|c|c|c|}
\hline No & Perception & Value & Remarks \\
\hline 1 & Village ecotourism management in Penglipuran & 6 & Agree \\
\hline 2 & $\begin{array}{l}\text { Cultural tourism village program carried out in } \\
\text { the long term }\end{array}$ & 6 & Agree \\
\hline 3 & The arrival of local and or foreign visitors & 6 & Agree \\
\hline 4 & $\begin{array}{l}\text { Visitor arrivals based on daily, weekly and annual } \\
\text { visit times }\end{array}$ & 6 & Agree \\
\hline 5 & $\begin{array}{l}\text { Media promotion of village ecotourism in the } \\
\text { form of visual }\end{array}$ & 4 & Mediocre \\
\hline
\end{tabular}

Source: Data Processed on 31 December 2019.

Note: 1 = strongly disagree $2=$ disagree $3=$ somewhat disagree $4=$ mediocre $5=$ somewhat agree 6 = agree 7 = strongly agree.

\subsection{Penglipuran Community Assessment of Environmental Impacts}

Environmental impacts by the information of indigenous peoples in the capacity of 30 respondents were divided into two impacts, positive impacts and negative impacts. That is because the management of cultural tourism villages has positive and negative impacts at each different place.

The assessment of Penglipuran Village community on the positive impact of the management of cultural tourism village that was carried out was agreed. That is because the indigenous people assess the existence of cultural tourism village management will not lead to safe and comfortable conditions due to the arrival of visitors who come. The assessment of nature conservation and environmental awareness still needs to be maintained and considered to be agreed by the community. That is because the management of cultural tourism villages carried out is related to the preservation of nature and culture so that it will create a relationship that is related between humans and the Creator, fellow, and with nature (Tri Hita Karana). The subsequent assessment of the area is well organized with adequate infrastructure conditions. The assessment agreed by the Pengllipuran Indigenous Village community because with the management of the cultural tourism village in Penglipuran, the indigenous people felt participated and were responsible for the condition of tourism objects and infrastructure that were getting better.

The assessment of the Penglipuran Indigenous Village community on the negative impact of the negative impact of the management of the cultural tourism village agreed. That is because the people of Penglipuran Indigenous Village rate the amount of environmental pollution that will damage the climatic conditions in the Penglipuran Indigenous Village. The management of cultural tourism villages which involve heavy equipment will have an impact on soil compaction that results in decreased soil fertility. The people of Penglipuran also considered that they strongly agreed that if the management of the tourism village of Budata, if not managed properly, would have an impact on the reduction of green land in the Penglipuran traditional village area. That is because the majority of the people's livelihoods are farmers and ranchers which can lead to lack of agricultural land and lack of food for livestock.

\subsection{Penglipuran Community Assessment of Economic Impacts}


The economic impacts that will take place during the cultural tourism village management activities carried out in Penglipuran Village consist of 2 types of these positive and negative impacts. The village ecotourism planning that will be carried out in Penglipuran Village has the assessment of 30 different respondents.

The assessment of the Penglipuran community on the management of the tourism village in the Penglipuran area on the positive economic impact of the majority of respondents agreed That is because cultural tourism activities will provide more inclusion to the people of Penglipuran Village. More income in Penglipuran Village is supported by a variety of livelihoods related to tourism activities such as development in the home industry. The development of livelihoods in the home industry will also affect the demand for local goods. That is because the arrival of visitors to a tourist site not only wants to see attractions, but, there must be something purchased in order to be collected.

Penglipuran's community assessment of the negative economic impacts is normal. That is because the Penglipuran community does not compete with other business actors. This can be seen from the healthy competition between farmers in Penglipuran Village. Lack of knowledge about the livelihoods of industrial houses by the people of Penglipuran Village makes the Penglipuran people not confident with the results to be sold to visitors. This makes the Penglipuran community's assessment of the incompatibility of local goods higher.

\subsection{Assessment of Penglipuran Communities on Socio-Cultural Impacts}

The socio-cultural impact is closely related to the management of the tourism village which will take place in Penglipuran Village. Penglipuran Village still has customs and high social relations between its people(Hakim \& Setiadi, 2016). The positive socio-cultural impact arising from the management activities of the cultural tourism village is that the positive socio-cultural impact by the Penglipuran community agrees. The Penglipuran community agreed with the existence of a cultural tourism village management activity that preserves the existing culture. The exchange of experience and the protection of cultural heritage are of ordinary value to the Penglipuran people. This is because the Penglipuran community has been contaminated by eastern culture. Penglipuran Village Community assesses that the cultural tourism village management activities carried out in Penglipuran Village can increase the socialization activities among Penglipuran Village communities because the mutual cooperation activities that will be carried out by the Village community for the sake of the smooth management of cultural tourism village activities in a sustainable manner as well as a pilot for other regions in Indonesia.

\subsection{Penglipuran Village Community Readiness for Management of Cultural Tourism Village}

Penglipuran village community readiness for the management of cultural tourism villages tend to be ready. That is because the Penglipuran community is ready in several factors that influence the creation of a cultural tourism village. The factors that fulfill the village's cultural tourism village activities include:

\subsubsection{Service Ethics for Visitors}

The people of Penglipuran Village assess that they are ready to carry out a service ethic for visitors. That is because the hospitality of the Penglipuran community makes the services to be implemented will be good. The hospitality is not enough because the Penglipuran people have not been able to provide the best in terms of appearance because the majority of Penglipuran villagers' livelihoods are farmers.

\subsubsection{Security and Safety of Visitors}

The safety and security of visitors is very important to establish good management of cultural tourism villages. The Penglipuran community is of the opinion that they are very ready to carry out visitor security activities by running a social security system to protect visitors from crime. The Penglipuran community also considered that they were willing to know about the safety of visitors and provide first aid kits for visitor safety.

\subsubsection{Business Competition}


Penglipuran Village Community considered that they were ready if business competition occurred between the community and other communities. That is because the people of Penglipuran Village consider that they are very ready to agree on the division of the area and sell products typical of the village community. The people of Penglipuran Village are of the opinion that it is normal to provide a place to stay for visitors due to the unavailability of a decent village house for visitors.

\subsubsection{Comfort and Cleanliness for Visitors}

Comfort and cleanliness become one of the factors of visitor assessment of a tourist attraction. Penglipuran Village Community believes that they are very ready to maintain the cleanliness of tourism objects by providing appropriate bins for visitors. The people of Penglipuran Village are also very ready to pay attention to environmental cleanliness by arranging a village cleaning schedule. Service ethics for visitors can be seen in Table 4.

Table 4. Service Ethics in Visitors

\begin{tabular}{lclll}
\hline No & Readiness & Value & \multicolumn{1}{c}{ Remarks } \\
\hline 1 & Ethics of service to visitors & 6 & Ready \\
2 & Safety and safety for visitors & 6,2 & Ready \\
& & & Ready \\
3 & Business competition & 6 & Very Ready \\
4 & Comfort and cleanliness for visitors & 7 &
\end{tabular}

Source: Data Processed on 31 December 2019.

Note: 1 = very not ready $2=$ not ready $3=$ somewhat not ready $4=$ mediocre $5=$ somewhat ready $6=$ ready $7=$ very ready

Penglipuran community respondents said they were ready for the management of Penglipuran cultural tourism village because it would have a positive impact on the community. Currently tourism has been developed as an industry in every country in the world. Attention to the tourism sector is now increasingly widespread because this is because people are starting to realize that tourism brings economic benefits and benefits for countries that receive tourist arrivals. Likewise in Indonesia, the government wants to develop tourism as an industry to support the level of business opportunities, employment opportunities, increasing the distribution of people's income. Often in its development in order to get the maximum economic benefit through the level of tourist visits, often managers of tourism activities are not fully aware that tourism really needs a good environment, but if the development does not pay attention to the carrying capacity of the environment to the number of tourists, of course it will cause negative impacts. With the high level of tourist visits that are characterized by nature-based, if a destination is managed without realizing the importance of carrying capacity of the environment, then the environment around which the tourism activities run little by little will be damaged. That is because the quality of the environment is the most fundamental thing for tourism. When tourism is now seen as a source of economic development, tourism activities can have a negative impact on the environment and also threaten the gradual loss of cultural heritage of an area, as well as worsening economic disparities between community groups.

To answer all these concerns an approach to sustainable tourism or environment-based tourism through the pilot of a cultural tourism village Penglipuran is important to be introduced to all stakeholders in tourism activities, namely the government, investors, the community, and even tourists. This is useful to change from just knowing to understanding how to carry out responsible tourism activities, in utilizing and enjoying biological natural resources. In order to prioritize the balance of the ecosystem more than just considering the extent and beauty of an area. Echoes of sustainable tourism approach is quite interesting in an effort to send moral messages to tourists to participate in sustainable tourism activities. This tourism activity approach can also meet the economic needs of tourism in income and profits in the tourism industry, tourism experience for tourists who are already saturated with glamorous tourism 
activities, especially for tourists with middle and upper income levels, and economic growth based on the environment and cultural protection for a country and its local people. One approach in developing alternative tourism is the development of rural tourism for sustainable rural development in the field of tourism. Village tourism is a form of integration between attractions, accommodation and supporting facilities that are presented in a structure of community life that integrates with applicable procedures and traditions.

\section{Conclusion and Recomendation}

Penglipuran Tourism Village Management is a tourism management model based on Tri Hita Karana, namely tourism management based on a balance philosophy the form of a harmonious relation between humans and the spiritual environment (Parhyangan), social environment (Pawongan), and physical environment (Palemahan). Tri Hita Karana Model based tourism management makes all three aspects of the environment both an object and a subject of tourism development. In its position as an object, the aspects of parhyangan, pawongan and palemahan function as sufficient tourist attraction potential to attract tourists. On the contrary, in its position as a subject, the values of the aspects of parhyangan, pawongan and palemahan become a moral basis that controls the direction of tourism development so as not to conflict with the principles of harmonious relations between humans and the spiritual environment, social environment, and physical environment. Thus, tourism management based on Tri Hita Karana in turn has a number of implications in the form of improving the economic welfare of the community, cultural revitalization and local environmental sustainability. It is very appropriate that other regions in Indonesia make Penglipuran traditional village as a model in order to maintain the existence of fulfilling the rights of indigenous peoples.

\section{References}

Azwar, W., Muliono, Permatasari, Y., Akmal, H., Ibrar, S., \& Melisa. (2019). Nagari Customary Justice System in West Sumatra. Jurnal Bina Praja, 11(1), 53-62. https://doi.org/10.21787/jbp.11.2019.53-62

Baker, R. (Rudy) B. (2010). Customary International Law in the 21st Century: Old Challenges and New Debates. European Journal of International Law, 21(1), 173-204. https://doi.org/10.1093/ejil/chq015

Hakim, B. R., \& Setiadi, A. (2016). Bali Traditional Settlement Morphology Analysis Penglipuran, Kubu Village, Bangli Regency, Bali Province. DIMENSI Journal of Architecture and Built Environment, 43(1), 47-54.

International Law Association, London Conference, F. R. of C. on F. of, \& Law, C. (General) I. (2000). Statement of Principles Applicable to the Formation of General Customary International Law.

Johnson, P. (2010). Realizing Rural Community Based Tourism Development: Prospects for Social-Economy Enterprises. Journal of Rural and Community Development, 5.

Ojha, H. R., Ghate, R., Dorji, L., Shrestha, A., Paudel, D., Nightingale, A., ... Kotru, R. (2019). Governance: Key for Environmental Sustainability in the Hindu Kush Himalaya. The Hindu Kush Himalaya Assessment, 545-578.

Priambodo, B. B. (2018). Positioning Adat Law in the Indonesia's Legal System: Historical Discourse and Current Development on Customary Law. Udayana Journal of Law and Culture, 2(2), 140-164. https://doi.org/10.24843/UJLC.2018.v02.i02.p02.

Purnamawati, I. G. A., Adnyani, N. K. S., \& Suastika, I. N. (2015). The Conservation of Perang Pandan Tradition for the Socio-Economic Life of Adat Community in Tenganan Pagringsingan Bali. In Procedia-Social and Behavioral Sciences (pp. 135-141). Denpasar, Bali: Science Direct, Elsevier. https://doi.org/10.1016/j.sbspro.2015.11.020

Riddle, C., \& Thompson-Fawcett, M. (2019). Rural change and tourism in remote regions: Developments and Indigenous endeavour in Westland, Te Tai o Poutini, Aotearoa New Zealand. New Zealand Geographer, 75(3), 194-203. https://doi.org/10.1111/nzg.12236 
Saleh, A. (2016). The strategic development of culture and heritage Tourism in Petra, Jordan (Case Study). https://doi.org/10.13140/RG.2.2.17171.12321

Sugiama, A. G. (2019). The Sustainable Rural Tourism Asset Development Process Based on Natural and Cultural Conservation. In Advances in Social Science, Education and Humanities Research (pp. 249-253). Atlantis Press. https://doi.org/10.2991/icastss-19.2019.52 
